JIKAP PGSD: Jurnal Ilmiah Ilmu Kependidikan

Vol,1. No,2. Tahun 2017

e-ISSN: 2597-4440 dan p-ISSN: 2597-4424

This work is licensed under a Creative Commons Attribution

4.0 International License

\title{
Penggunaan Gambar Luas Daerah Untuk Meningkatkan Pemahaman Siswa Terhadap Operasi Penjumlahan Bilangan Pecahan SD Kabupaten Bone
}

\author{
Iriani Sidji \\ Sekolah Dasar Negri 9 Ta’ Dinas Pendidikan Kabupaten Bone \\ Email: irianisidji@gmail.com
}

\begin{abstract}
Abstrak. Tujuan penelitian ini adalah untuk meningkatkan pemahaman dalam menjumlahkan pecahan dengan menggunakan gambar luas daerah siswa kelas IV SD Negeri 9 Ta'. Jenis penelitian tindakan dengan siklus meliputi perencanaan, pelaksanaan, observasi, dan refleksi. Data penelitian adalah data aktifitas dan hasil belajar siswa dalam penjumlahan pecahan. Data diperoleh dengan observasi, tes, catatan lapangan. Hasil penelitian ini yaitu pada siklus I (1) penajian pada tahap presentase dalam mempragakan gambar luas daerah belum maksimal (2) siswa mengalami kesulitan dalam menjumlahkan pecahan (3) kerja kelompok belum maksimal, sedangakan pada siklus II telah menunjuhkan peningkatan yang signifikan yaitu (1) penyajian pada tahap presentase dalam mempragakan gambar luas daerah telah maksimal berjalan sesuai dengan rencana (2) siswa merasa senang mengerjakan soal penjumlahan pecahan dengan menggunakan gambar luas daerah (3) siswa dapat menyajikan langka-langka penjulahan pecahan dengan menggunakan gambar luas daerah, Peningkatan itu dapat dilihat pada siklus I kualifikasi kurang (K), siklus II kualifikasi baik (B). Berarti dengan menggunakan gambar luas daerah dalam pembelajaran pecahan dapat meningkatkan hasil belajar siswa kelas IV SD Negeri 9 Ta'.
\end{abstract}

Kata kunci: Penjumlahan pecahan, Media Pembelajajaran

Abstract. The purpose of this research is to increase the understanding in summing the fractions by using the wide picture of the fourth grade student area of SD Negeri $9 \mathrm{Ta}$ '. Types of action research with cycles include planning, execution, observation, and reflection. Research data is activity data and student learning result in addition of fraction. Data obtained by observation, test, field notes. The result of this research is in cycle I (1) study at the stage of percentage in mempragakan image area not maximal yet (2) students have difficulties in adding fraction (3) group work not yet maximal, meanwhile in cycle II has significant increase that is (1) presentation at the presentation stage of the picture of the width of the area has been maximally run in accordance with the plan (2) the students are happy to do the sum of the fractions by using the broad area picture (3) the students can present the rare of fractional disappearance using the area wide image, can be seen in cycle I less qualification (K), cycle II qualification good (B). Means by using the image area in the fractional learning can improve student learning outcomes fourth grade SD Negeri 9 Ta'.

Keywords: The sum of fractions, Media Education

\section{PENDAHULUAN}

Matematika sebagai ilmu dasar sangat memegang peranan penting dalam pengembangan ilmu pengetahuan dan teknologi, misalnya dalam pengembangan ilmu ekonomi, biologi, kimia dan fisika memerlukan 
matematika. Karena peranan yang demikian itu maka seharusnya matematika dikuasai sedini mungkin oleh para siswa baik aspek terapannya maupun aspek penalarannya.

Ditinjau dari aspek terapannya matematika sebaiknya dalam pembelajaran di informasikan kepada siswa bahwa materi yang diajarkan dapat diterapkan pada bidang apa saja, utamanya yang berkaitan dengan kehidupan sehari-hari. Ditinjau dari aspek penalarannya juga diinformasikan kepada siswa bahwa matematika merupakan sarana untuk berfikir logis, analitis dan sistematis.

Dengan adanya kedua hal di atas siswa akan mengetahui manfaat praktis dari belajar matematika, khususnya pada operasi penjumlahan pecahan merupakan materi yang sangat esensial karena akan dipelajari dan digunakan dalam pelajaran matematika pada jenjang pendidikan berikutnya.

Dalam KTSP ada beberapa kajian materi yang harus dikuasai siswa sekolah dasar. Salasatu bahan kajian itu adalah pecahan, konsep dan keterampilan yang tercakup dalam pecahan sangat baik dalam memberikan apersepsi dan pengalaman bagi siswa untuk belajar lebih bermakna, siswa yang melihat secara langsung pengertian konsep-konsep dari suatu materi pada benda-benda konkrit yang sedang diperagakan dapat menimbulkan motivasi dan minat belajar siswa sekolah dasar Nurfaida, (Soewito,1992: 5). Ditinjau dari rana kognitif sebenarnya tujuan utama pelajaran matematika itu adalah pencapaian transfer belajar, segala usaha yang dikerahkan agar siswa berhasil menguasai pengetahuan dan keterampilan matematika untuk dapat memecahkan masalah-masalah, baik pada matematika itu sendiri maupun pada ilmu yang lain (Hudoyo, 1990: 102)

Dengan mengkonkretkan materi yang abstrak akan memberikan kesempatan bagi siswa untuk dapat mengembangkan kemampuannya dalam menciptakan suasana belajar yang kondusif, dan guru dapat menerapkan pembelajaran matematika yang sesuai dengan materi yang disajikan, sebagaimana pendapat J. Piaget (Muhsetyo, 2005: 19) menyatakan bahwa anak-anak usia sekolah dasar $7-12$ tahun masih berada dalam tahap operasional konkret.

Untuk menciptakan pemahaman siswa, pengkonkretan obyek-obyek yang akan dipelajari akan membentuk pemahaman yang bermakna pada diri dan dapat meningkatkan siswa. Matematika sebagai ilmu dan struktur dalam hubungannya dengan simbol-simbol yang diperlukan. Simbol-simbol itu sangat penting untuk membantu memanipulasi aturan-aturan operasi yang ditetapkan, dan simbol-simbol juga dapat menjamin adanya komunikasi dan mampu memberikan keterangan untuk membentuk suatu konsep baru (Hudoyo, 1990: 5). Selama ini pembelajaran matematika masih mengikuti kebiasaan dengan urutan materi-materi pelajaran seperti : (1) diajarkan teori/defenisi/teorema, (2) diberikan contoh-contoh, (3) diberikan latihanlatihan soal. Soedjadi (Ingana, 2003: 3).

Dalam mempelajari suatu matematika yang baru pengalaman-pengalaman belajar dari seseorang itu akan mempengaruhi terjadinya belajar matematika, Depdikbud, (Hudoyo, 1990: 4) sampai saat ini penguasaan siswa terhadap materi matematika masih merupakan masalah dalam dunia pendidikan Indonesia. Tentunya banyak faktor sebagai penyebab materi matematika yang tidak dikuasai siswa, utamanya pada sekolah dasar misalnya disebabkan kemampuan siswa, pendekatan pembelajaran yang digunakan guru, sarana belajar, penguasaan guru terhadap materi yang diajarkan dan karakteristik siswa.

Untuk dapat memecahkan masalahmasalah yang terjadi di sekitarnya, misalnya penyelesaian soal-soal cerita, luas, dan volume bangun-bangun geometri. Semuanya membutuhkan pengetahauan operasi pecahan, maka sangatlah penting penggunaan bendabenda konkret agar mudah dipahami siswa, jika bentuk abstrak dibuatkan konkretnya yang tepat dalam mengajarkannya Hudoyo (1996: 12).

Berdasarkan hasil observasi di SD Negeri 9 Ta' diperoleh informasi dari guru bahwa masih banyak materi matematika di sekolah dasar belum dikuasai siswa salasatunya adalah bilangan pecahan dan operasinya. Berdasarkan hasil observasi peneliti terhadap guru di SD Negeri 9 Ta' terindikasi bahwa mereka telah mengajar dengan baik namun siswa belum juga menguasai sepenuhnya, ini disebabkan karena guru mengajar tidak menggunakan benda konkret, guru berangapan bahwa menggunakan alat peraga hanya memakan waktu yanga lama sehingga waktu mengajar yang direncanakan tidak di laksanakan dengan efisien keadaan seperti ini membuat siswa tidak maksimal menyerap pelajaran yang disajikan oleh guru, sehinggga siswa tidak memahami pembelajaran khususnya operasi penjumlahan bilangan pecahan, guru hanya memberikan penjelasan- 
penjelasan materi yang berupa penjelasan dan pemberian soal-soal latihan, tanpa mengkonkretkan bilangan-bilangan pecahan yang diajarkan.

Pemberian konsep terhadap siswa terkait dengan penjumlahan pecahan sangat lemah. Hal ini karena tidak adanya media yang digunakan oleh guru untuk membangkitkan skemata siswa terhadap apa yang tengah dipelajari. Guru tidak dapat memberikan konsep tentang tata cara penjumlahan pecahan yang berpenyebut sama dan pecahan yang berpenyebut tidak sama. Indikasi seperti ini memberikan kesan bahwa guru belum memberikan sistem pembelajaran yang maksimal kepada siswa sehingga skemata siswa selalu monoton.

Kondisi di atas terkesan bahwa guru di SD Negeri 9 Ta' belum menggunakan benda konkret dalam menyajikan materi matematika khususnya pada pembelajaran penjumlahan pecahan, serta kurang melibatkan siswa dalam pembelajaran, seperti peragaan benda konkret, siswa tidak diajak untuk mendemonstrasikan alat peraga yang telah di persiapkan oleh guru. Guru hanya menggunakan metode ceramah dalam menyampaikan materi dan menyelesaikan soal soal dalam penjumlahan pecahan, sehingga tidak tertanam konsep operasi penjumlahan pecahan pada diri siswa. Hal ini sejalan dengan (Hudoyo 1990 : 51) bahwa pelajaran Matematika yang sifatnya abstrak, deduktif dan berjenjang adalah dengan memanipulasi obyekobyak yang abstrak dalam bentuk konkret.

Bilangan pecahan dan operasinya mulai diajarkan sejak kelas VI sekolah dasar, yaitu dengan memperkenalkan konsep pecahan, pecahan senilai, membandingkan pecahan dan operasi penjumlahan bilangan pecahan yang sederhana. Materi pecahan ini dipelajari kembali dan dikembangkan di kelas VI dan kelas VI sekolah dasar.

Untuk mengajarkan operasi hitung bilangan pecahan di sekolah dasar, utamanya di kelas VI diperlukan suatu alat peraga yang tepat. Karena berkaitan dengan penanaman konsep dasar. Salasatu teknik yang dapat digunakan adalah dengan menggunakan alat peraga media gambar (persegi, persegi panjang, segi tiga, dan lingkaran) agar dapat meningkatkan meningkatkan kemampuan siswa terhadap operasi penjumlahan bilangan pecahan. Melalui alat peraga dapat dijelaskan konsep pecahan, pecahan senilai, membandingkan pecahan dan operasi bilangan pecahan secara nyata.
Pengajaran dengan menggunakan alat peraga akan memberikan hasil belajar siswa lebih cepat, lebih meningkat, dan lebih menarik Livie \& Livie (Arsyad, 2004: 9) mengatakan bahwa belajar melalui stimulus gambar dan stimulus visual membuahkan hasil belajar yang lebih baik seperti mengingat, mengenali, mengingat kembali dan menghubunghubungkan fakta dan konsep. Perbandingan pemerolehan hasil belajar melalui indera pandang dan indera dengar sangat menonjol perbedaannya. Kurang lebih $90 \%$ hasil belajar seseorang diperoleh melalui indera pandang dan hanya sekotar $5 \%$ diperoleh melalui indera dengar, kemudian $5 \%$ lagi dengan indera lainnya, Achsin, (Arsyad, 2004:10)Dari penjelasan di atas tampak bahwa pembelajaran dengan menggunakan alat peraga (luas daerah bangun persegi, persegi panjang, segitiga, dan lingkaran) menguatkan pemahaman siswa kelas VI SD Negeri Kadolomoko terhadap permasalahan operasi penjumlahan bilangan pecahan dan dapat meningkatkan kreativitas siswa dalam menyelesaikan suatu permasalahan yang ada dalam operasi penjumlahan pecahan.

Dari sekian faktor-faktor penyebab materi tidak dikuasai siswa, dalam penelitian ini, penulis hanya meneliti satu faktor yaitu yang berkaitan dengan penggunaan alat peraga yang digunakan guru dalam mengajarkan matematika. Berdasarkan pada uraian pada latar belakang di atas, penulis melakukan suatu penelitian tindakan dengan judul "Penggunaan Gambar Luas Daerah untuk Meningkatkan Pemahaman Siswa Terhadap Operasi Penjumlahan Bilangan Pecahan di Kelas VI SD Negeri 9 Ta' Kabupaten Bone.

Berdasarkan latar belakang $\mathrm{di}$ atas, penulis menemukan masalah yaitu bagaimana penerapan penggunaan gambar luas daerah dalam menyelesaikan penjumlahan bilangan pecahan pada Siswa Kelas VI SD Negeri 9 Ta'.

Tujuan penelitian ini adalah untuk meningkatkan pemahaman siswa terhadap konsep penjumlahan bilangan pecahan dengan menggunakan gmbar luas daerah pada Siswa Kelas VI SD Negeri 9 Ta'.

Untuk memecahkan permasalahan di atas dilakukan dengan tindakan-tindakan sesuai merencenakan tiga tahap tindakan yaitu: (a) penanaman konsep pecahan dengan menggunakan gambar luas daerah, pada tahap ini di perlihatkan gambar-gambar bangun datar persegi, persegi panjang, segi tiga dan lingkaran. Kemudian penulis menjelaskan bahwa apa bila 
bangun-bangun tersebut dibagi sama besar maka hasilnya adalah seperdua, begitupun menjelaskan bilangan pecahan yang lain, (b) pecahan senilai dengan menggunakan luas daerah, pada tahap ini juga siswa dijelaskan pulah bahwa bilangan pecahan senilai merupakan bilangan yang sama nilainya bila dibagidengan menampilkan gambar luas daerah, (c) penjumlahan dengan menggunakan gambar luas daerah, penjumlahan pecahan merupakan menjumlahkan bagian-bagian dari satu kesatuan yang utuh dibagi sama besar dengan menampilkan gambar luas daerah serta menjelaskanya. Selanjutnya diakhiri dengan melakukan evaluasi untuk mengetahui kemajuan pelaksanaan tindakan

\section{METODE PENELITIAN}

Penelitian ini adalah Penelitian Tindakan Kelas (PTK) karakteristik yang khas dari penelitian ini yakni tindakan-tindakan (aksi) yang berulang-ulang untuk memperbaiki proses belajar mengajar di kelas. Model tindakan yang dilakukan dalam penelitian ini sesuai dengan pendapat Kemmis dan Mc Taggart (Latri, 2003: 21) yang menyatakan bahwa proses penelitian tindakan merupakan sebuah siklus atau proses daur ulang yang terdiri dari empat aspek fundamental diawali dari aspek mengembangkan perencanaan kemudian melakukan tindakan sesuai dengan rencana, observasi/pengamatan terhadap tindakan, dan diakhiri dengan melakukan refleksi. Kegiatan penelitian ditempuh dalam suatu tahapan sehingga pemahaman siswa terhadap penggunaan luas gambar luas daerah dalam menjumlahkan pecahan diharapkan dapat tercapai secara maksimal.

Yang menjadi subyek penelitian adalah siswa SD Negeri 9 Ta' yang aktif dan terdaftar pada semester genap tahun ajaran 2015/2016 dengan sasaran utama meningkatkan kemampuan siswa memahami konsep operasi penjumalah bilangan pecahan melalui penggunaan gambar luas daerah.

Memilih siswa kelas VI sebagai subyek penelitian karena (1) masih ditemui siswa mengalami kesulitan dalam operasi penjumlahan bilangan pecahan, (2) di sekolah ini belum dilakukan penelitian yang menggunakan gambar luas daerah dalam penjumlahan pecahan, (3) adanya dukungan dari kepala sekolah dan guru terhadap pelakanaan penelitian ini
Untuk mejawab permasalahan di atas, ada beberapa factor yang akan diselidiki, yaitu :

1. Faktor Siswa, yaitu dengan melihat apakah tingkat kemampuan siswa pada pokok bahasan penjumlahan pecahan dalam kategori rendah, sedang atau tinggi.

2. Faktor guru yaitu dengan memperhatikan bagaimana persiapan materi dan kesesuaian pendekatan pembelajaran yang digunakan dalam pembelajaran penjumalahan pecahan.

3. Faktor sumber belajar yaitu dengan memperhatikan sumber belajar yang digunakan apakah sesuai dengan tujuan yang hendak dicapai, demikian pula latihanlatihan yang diberikan, apakah sudah berjenjang sesuai dengan tingkat kemampuan siswa serta dengan tujuan yang akan dicapai sesuai dengan tahapan penggunaan gambar luas daerah sebagai media pembelajaran.

Sesuai dengan jenis penelitian yang telah dikemukakan sebelumnya, mka kehadiran peneliti di lapangan sangat diperlukan. Dalam penelitian ini peneliti berfungsi sebagai instrument kunci dan pemberi tindakan. Sebagai intrumen kunci, artinya peneliti sebagai pengamat, dan pewawancara. Sebagai pengamat, peneliti mengamati aktivitas siswa selama berlangsungnya kegiatan pembelajaran. Sebagai pewawancara, peneliti mewawancarai subyek penelitian berdasarkan jawaban yang telah diberikan pada setiap tes atau tugas yang telah dikerjakan. Dalam kedudukannya sebagai pemberi tindakan, peneliti bertindak sebagai pengajar yang membuat rancangan pembelajaran dan sekaligus sebagai penyaji bahan ajar selam berlangsungnya kegiatan penelitian. Di samping itu peneliti juga sebagai pengumpul data dan penganalisis data serta sebagai pelopor hasil penelitian. Dalam kegiatan pengamatan dan pengumpulan data, peneliti dibantu oleh guru kelas dan teman sejawat.

a) Data

Penelitian ini berupa hasil pekerjaan siswa terhadap soal yang diberikan yang meliputi (1) tes awal sebelum tindakan, (2) hasil wawancara dengan subyek penelitian, (3) hasil pengamatan selama pembelajaran berlangsung, (4) hasil catatan lapangan tentang kegiatan pembelajaran yang berkitan dengan tindakan.

b) Sumber data

Sumber data penelitian ini adalah seluru siswa kelas VI SD Negeri 9 Ta' 
berdasarkan hasil tes awal yang telah di berikan.

Untuk pengumpulan Data dalam penelitian ini di lakukan dengan tes, wawancara, pengamatan, dan catatan lapangan. Empat teknik tersebut diuraikan sebagai berikut:

a) Tes

Tes dilakukan untuk mengmpulkan informasi tentang pemahaman siswa konsep penjumlahan pecahan. Tes di laksanakan pada awal penelitian, pada akhir setiap tindakan, dan pada akhir setelah diberikan serangkaian tindakan.

b) Wawancara

Wawancara dimaksudkan untuk manggali kesulitan siswa dalam memahami konsep penjumlahan pecahan, yang mungkin sulit di peroleh dari hasil pekerjaan siswa maupun melalui pengamatan.

c) Pengamatan

Pengamatan dilaksanakan oleh orang yang terlibat aktif dalam pelaksanaan tindakan yaitu guru yang mengajar di kelas VI dan teman sejawat. Pada pengamaatan ini di gunakan pedoman pengamatan untuk mencatat hal-hal yang di anggap penting

d) Catatan Lapangan

Catatan lapangan memuat hal-hal penting yang terjadi selama pembelajaran berlangsung yang dapat digunakan untuk melengkapi data yang tidak terekam dalam lembar observasi.

Analisis data dalam penelitian ini dilakukan selama dan sesuda pengumpulan data. Analisis data dilakukan dengan membandingkan hasil pengamatan, Wawancara, Catatan lapangan dengan indikator-indikator pada tahap refleksi dari data penelitian. Data yang terkumpul dianalisis dengan menggunakan analisis kualitatif yang dikembangkan oleh Miles dan Huberman (1992:18) yang terdiri dari tiga tahap kegiatan yang dilakukan secara berurutan, yaitu: (1) mereduksi data, (2) menyajikan data, (3) menarik kesimpulan, (4) vertifikasi data.

Untuk mengecek keabsahan data digunakan teknik triangulasi dan teknik diskusi sengan teman sejawat. Menurut Moleong (1998:178) triangulasi dalah teknik pengecekan keabsahan datayang mwlibatkan sesuatu yang lain di luar data itu untuk keperluan pengecekan atau sebagai pembanding terhadap data itu.

Ada dua teknik triangulasi yang dilakukan dalam penelitian ini, triangulasi dengan metode dan triangulasi dengan sumber. Triangulasi dengan metode dilakukan dengan cara membandingkan dan mengecek balik sesutu informasi yang diproleh melalui observasi, wawancara, catatan lapangan, dan tes akhir tindakan. Triangulasi dengan sumber dilakukan dengan cara membandingkan data hasil observasi teman sejawat dan observasi peneliti dengan hasil wawancara.

Diskusi dengan teman sejawat dan guru sebagai pengamat dalam penelitan ini dimaksudkan untuk membicarakan proses dan hasil penelitian kemudian merencanakan tindakan selanjutnya.

Dalam penelitian ini, penulis terlebih dahulu melakukan tes awal berupa tes diagnostic untuk mengetahui kemampuan awal siswa, sebelum diberikan tindakan. Selain tes awal, penulis juga melakukan observasi awal untuk mengetahui ketetapan tindakan yang akan diberika dalam rangka meningkatkan hasil belajar matematika khususnya penjumlahan pecahan.

Dari hasil evaluasi dan observasi awal,maka dalam refleksi ditetapkan tindakan yang digunakan untuk menungkatkan hasil belajar matematika siswa, yaitu melalui pembelajaran dengan menggunakan gambar luas daerah sebagai media pembelajaran.

Berdasarkan refleksi awal tersebut maka penelitian tindakan kelas ini dilaksanakan dengan prosedur sebagai berikut :

a) Perencanaan

Kegiatan yang dilakukan dalam tahap perencanaan ini meliputi :

1 Membuat scenario pembelajaran dalam melaksanakan tindakan

2 Membuat lembar observasi untuk melihat bagaimana suasan belajar mengajar di kelas saat penggunaan gamabr luas daerah diaksanakan

3 Membuat kusioner untuk mengumpulkan data tentang tanggapan siswa mengenai pelaksanan metode penggunaan gambar luas daerah dalam pembelajaran.

4 Membuat alat bantu mengajar yang diperlukan dalam rangka membantu siswa memahami konsep-konsep matematika khususnya operasi penjumlahan pecahan dengan baik.

5 Mendesain alat evaluasi untuk meningkatkan pemahaman siswa terhadap materi penjumalahan pecahan.

b) Pelaksanan Tindakan 
Tindakan penelitian ini dilakukan menurut model yang dikemukakan oleh Kemmis dan Mc Taggart (Latri, 2003: 21) yang meliputi kegiatan perencanaan, pelasksnan tindakan, observasi dan refleksi. Tindakan yang telah dirancang dan dilaksanakan oleh penulis berkolaborasi dengan teman sejawat dan guru kelas VI SD Negeri 9 Ta'. Pembelajaran yang dilakukan penulis dengan menggunakan gambar luas daerah sebagai media pembelajaran dengan skenario pembelajaran yang telah dibuat.

Kriteri keberhasilan untuk tindakan, apabila siswa telah memahami konsep operasi penjumalahan bilangan pecahan dengan menggunakan gambar luas daerah sebagai media pembelajaran.

c) Observasi

Observasi dilaksanakan dengan menggunakan lembar observasi yang telah dibuat. Proses observasi dilakukan oleh penulis untuk mengamati guru dalam kelas selama melaksanakan tindakan dalam proses pembelajaran dengan menggunakan gambar luas daerah sebagai media, pengamatan juga dilakukan terhadap prilaku dan aktivitas siswa selama proses pembelajaran berlangsung dan dampak yang ditimbulkan dari prilaku guru terhadap siswa selama proses pembalajaran.

d) Refleksi

Refleksi dilaksanakan pada akhir siklus pelaksanaan tindakan, refleksi tersebut ditujukan untuk memenuhi ada atau tidak adanya peningkatan hasil belajar matematika pada pokok bahasan yang diajarkan. Alat evaluasi yang digunakan adalah tes hasil belajar yang disusun penulis. Apabila secara klasikal siswa telah memperoleh nilai 6,5 paling rendah maka tindakan dianggap telah berhasil dilaksanakan. Dan apa bila nilai yang diperoleh siswa belum mencapai standar yang diharapkan maka dilanjutkan pada tahap siklus berikutnya, Dengan melihat kelemahan-kelemahan pada pembelajaran sebelumnya seperti

1) Data situasi pelaksanaan gambar luas daerah dengan menggunakan lembar observasi

2) Data tanggapan siswa terhadap pelaksanaan penggunaan gambar luas daerah dengan menggunakan kuisioner.
3) Data refleksi diri serta perubahanperubahan yang terjadi dalam kelas, diambil dengan menggunakan jurnal

4) Data tentang hasil belajar penjumlahan pecahan diambil dengan menggunakan tes hasil belajar

\section{HASIL DAN PEMBAHASAN}

Pada hari Senin 5 Mei 2015 peneliti menemui kepala sekolah, guru kelas VI sebagai guru mata pelajaran matematika di kelas VI SD Negeri 9 Ta' untuk membicarakan rencana penelitian. Peneliti juga menyampaikan rencana pelaksanaan tes awal pada pertemuan tersebut kepala sekolah memberikan izin pelaksanaan penelitian dan mempersilahkan berhubungan langsung dengan guru kelas VI dalam menetapkan jadwal pelaksanan tes awal dan rencana pelaksanaan tindakan penelitian.

Dalam diskusi antara peneliti, dan guru kels IV disepakati bahwa tes awal dilaksanakan pada hari Rabu 8 Mei 2015 mulai pukul 09.2009.50 WITA. Tes awal diikuti oleh semu siswa kelas VI SD Negeri 9 Ta' yang berjumlah 23 siswa. pada pelaksanaan tes awal, peneliti dibantu oleh guru kelas VI.

Pada hari Senin tanggal 11 Mei 2015 peneliti membicarakan hasil tes awal dengan guru kelas VI untuk merencanakan penelitian terhadap seluruh siswa kelas VI. Pada kesempatan yang sama disepakati juga bahwa pelaksanaan siklus I dimulai pada hari Senin tanggal 16 Mei 2016 setelah tes awal dilaksanakan. Berdasarkan dari tes awal yang diperoleh sebagian siswa belum memahami penjumlahan pecahan, selanjutnya dimasukkan dalam format dengan pembelajaran menggunakan luas daerah sebagai media pembelajaran. Dengan memungkinkan siswa dapat melihat langsung konsep- konsep penjumlahan secara nyata dari luasan daerah persegi.

Siswa kelas VI sebagai subyek penelitian, selanjutnya peneliti mengadakan wawancara dengan subyek penelitian pada hari Rabu tanggal 13 Mei 2016 mulai pukul 10.00-11.15 WITA. Wawancara dimaksudkan untuk mengetahui sejauh mana siswa dapat memahami materi prasyarat untuk materi penjumlahan pecahan. Siswa yang dijadikan subyek penelitian adalah seluruh siswa kelas VI SD Negeri 9 Ta'.

Berdasarkan hasil tes awal diperoleh informasi bahwa subyek penelitian dapat menjawab soal no 1,2 , sedangkan untuk $3,4,5$ masih melakukan kesalahan yaitu pada pola 
menentukan lambang bilangan yang diarsir. Skor tes awal dapat pada lampiran 14. Subyek penelitian hanya sebagian menjawab soal no 1 dan 2 dengan benar. Sedangkan untuk soal no 3,4,5 masih melakukan kesalahan dalam menjawab soal. Setiap bagian masih terdapat kesalahan.untuk mengetahui alasan jawaban yang belum dipahami subyek penelitian, maka dilakukan wawancara. Berdasarkan tes awal dan wawancara, disimpulkan bahwa masih dirasa perlu meningkatkan pemahaman siswa operasi penjumlahan pecahan .

Rencana pembelajaran untuk setiap tindakan telah disusun dan telah dikonsultasikan dengan dosen pembimbing. Rencana pembelajaran memuat (1) sub pokok bahasan, kelas/semester, dan waktu, (2) indikator pembelajaran (3) materi pembelajaran (4) materi prasyrat, (5) alat dan sumber dan (6) kegiatan pembelajaran.

Untuk mengamati aktivitas guru (peneliti) dan siswa selama pembelajaran digunakan tahapan lembar pengamatan. Pengamatan terhadap kegiatan-kegiatan pembelajaran dalam penelitian ini melibatkan 1 orang pengamat yaitu guru kelas VI SD Negeri 9 Ta' dan seorang teman sejawat. Lembar pengamatan dapat dilihat pada lampiran 4 untuk siklus I, dan lampiran 9 untuk siklus II.

Dalam pelaksanaan tindakan pembelajaran, dengan menggunakan gambar sebagai media peneliti bertindak sebagai guru. Tahap-tahap pembelajaran setiap tindakan yaitu penanaman konsep pecahan, pecahan senilai, dan penjumlahan pecahan.

Deskripsi pembelajaran untuk keaktifan belajar dengan menggunakan gambar sebagai media pada penjumlahan pecahan biasa penyebut tidak sama disajikan sebanyak dua kali tindakan pembelajaran. Adapun perincian setiap tindakan pembelajaran adalah sebagai berikut:

\section{a. Rencana Pelaksanaan Tindakan Siklus 1}

Materi pembelajaran yang dilaksanakan pada siklus 1 adalah penjumlahan pecahan biasa berpenyebut tidak sama yang masing-masing pembilangnya I. Pada awal pembelajaran siswa diingatkan kembali tentang macam-macam pecahan dalam bentuk luas daerah yang diarsir, menentukan KPK dari dua bilangan dan menentukan pecahan senilai. Pembelajaran tindakan dilaksanakan dalam satu kali pertemuan dengan alokasi waktu $2 \times 35$ menit

Indikator pembelajaran adalah siswa mampu melakukan penjumlahan, pengurangan, perkalian, dan pembagian pecahan. Sedangkan tujuan pembelajaran, (1) siswa dapat menentukan langkah-langkah untuk menyelesaikan soal-soal penjumlahan pecahan biasa berpenyebut tidak sama dan salah satu penyebutnya merupakan kelipatan penyebut yang lain serta masing-masing pembilangnya, (2) dapat menentukan langkah-langkah untuk menyelesaikan soal-soal penjumlahan pecahan biasa berpenyebut sama dan tidak sama dan penyebutnya bukan kelipatan penyebut yang lain serta masing-masing pembilangnya 1.

Evaluasi yang diberikan adalah memberikan tes secara tertulis tentang penjumlahan pecahan biasa berpenyebut tidak sama dengan menggunakan bagian daerah yang diarsir pada persegi panjang, segitiga, dan lingkaran.

Pelaksanaan pembelajaran ini memerlukan alat peraga. Untuk itu peneliti menyiapkan karton berbentuk persegi panjang, segitiga, dan lingkaran dengan daerah yang diarsir pada luasan daerah. Sebelum peragaan dilakukan guru, terlebih dahulu guru mempresentasekan di kelas.

\section{b. Pelaksanaan Tindakan siklus I}

Siklus I dilaksanakan pada hari Senin tanggal 17 Mei 2016 mulai pukul 09.40-11.00 WITA pembelajaran untuk tindakan I berlangsung selama 70 menit. Dalam pelaksanaan tindakan, peneliti bertindak sebagai guru. Mengawali tindakan pembelajaran ini peneliti mengucapkan salam kemudian menyampaikan topik yang akan dipelajari yaitu penjumlahan bilangan pecahan dengan menggunakan gambar luas daerah bagian dari suatu daerah luasan yang berbentuk persegi panjang, segitiga dan lingkaran setelah itu peneliti menyampaikan tujuan yang ingin dicapai.

\section{c. Hasil Observasi Tindakan siklus 1}

Pembelajaran tindakan siklus 1 diamati oleh dua orang pengamat yaitu seorang teman sejawat dari SD yang bersangkutan dan guru kelas VI sebagai guru matematika di SD Negeri 9 Ta'. Mereka melaporkan bahwa peneliti dalam pembelajaran tindakan 1 telah melaksanakan tugas sebagai berikut

1. Peneliti menyampaikan materi yang dibahas dan menginformasikan indikator pembelajaran serta menjelaskan materi yang mendukung tugas yang akan diselesaikan siswa 
2. Peneliti menggali pengetahuan yang dimiliki siswa sesuai dengan topik yang dibahas

3. Peneliti mengaitkan pelajaran dengan pengetahuan tes awal

4. Peneliti selalu membimbing siswa apabila ada siswa yang mengalami kesulitan dalam menyelesaikan soal penjumlahan pecahan yng telah di beriakan

5. Peneliti mendorong siswa agar meminta bantuan kepada teman kelompok sebelum meminta bantuan kepada guru

6. Peneliti meminta siswa membuat rangkuman materi pembelajaran penjumlahan pecahan dengan menggunkan daerah bagian yang di arsir terhadap kegiatan siswa peneliti melaporkan sebagai berikut:

7. Siswa dapat menentukan langkah-langkah untuk menyelesaikan soal penjumlahan pecahan biasa berpenyebut tidak sama yang masing-masing pembilangnya 1 dengan daerah bagian dari suatu luasan yang diarsir.

8. Siswa memberi respon senang yang merupakan hal yang baru terhadap proses pembelajaran, materi pembelajaran, cara belajar, cara guru mengajar serta suasana kelas yang menyenangkan

\section{d. Analisis dan Refleksi Tindakan Siklus 1 Pembelajaran tindakan siklus 1} difokuskan pada penjumlahan pecahan biasa berpenyebut tidak sama dan masing-masing pembilangnya 1 dengan menggunakan daerah bagian dari suatu derah luasan. Pembelajaran dilaksanakan dengan menerapkan pembelajaran dengan menggunakan gambar luas daerah sebagai media. Untuk memperoleh data tentang pelaksanaan tindakan siklus1 dilakukan pengamatan, wawancara, tes, dan catatan lapangan. Hasil pengamatan, wawancara, tes dan catatan lapangan selama pelaksanaan tindakan dianalisis dan didiskusikan dengan pengamat sehingga diperoleh hal-hal sebagai berkut :

1. Penyajian pada tahap presentase untuk memperagakan penjumlahan pecahan biasa berpenyebut tidak sama dengan menggunakan daerah bagian dari suatu daerah luasan berjalan sebagaimaa yang telah direncanakan, namun untuk belajar dengan menggunakan gambar sebagai media disiapkan waktu yang cukup untuk kegiatan tersebut.

2. Siswa mengalami kesulitan dalam mengerjakan soal penjumlahan pecahan dengan alat peraga berupa karton yang berbentuk persegi panjang, segitiga, dan lingkaran. Kesulitan yang dialami siswa adalah belum memahami makna pecahan yang ada pada alat peraga yang diberikan.

3. Kerja kelompok siswa belum maksimal karena masih banyak siswa yang melakukan aktivitas lain pada saat diskusi kelompok.

4. Pembelajaran secara kelompok masih didominasi oleh siswa yang berkemampuan tinggi sehingga keaktifan siswa yang lain masih kurang.

5. Sebagian besar siswa masih ragu-ragu dalam mengemukakan ide atau pendapat bila ditanya oleh guru terkait dengan pembelajaran.

6. Masih banyak ditemukan siswa yang raguragu untuk menanyakan hal-hal yang dianggap belum jelas baginya.

Berdasarkan analisis dan refleksi pada tindakan siklus 1 dan mengacu pada kriteria sukses yang ditetapkan maka pembelajaran pada tindakan siklus 1 belum berhasil, dimana berdasarkan hasil tes masih ditemukan siswa yang mencapai nilai kurang dari 6,5. hasil tes siswa dapat dilihat pada lampiran 15 .

a. Perencanaan Siklus II

Hasil analisis dan refleksi pada tindakan siklus 1, semua subyek penelitian secara umum sudah mencapai indikator pembelajaran namun yang diharapkan yaitu dapat menentukan langkah-langkah untuk menyelesaikan soal-soal penjumlahan pecahan biasa berpenyebut tidak sama yang masing-masing pembilangnya 1 dan yang salasatu penyebutnya merupakan kelipatan penyebut yang lain. bukan kelipatan salah satunya, dengan luas daerah bagian yang diarsir. Karena itu pembelajaran dilanjutkan dengan pembelajaran tindakan siklus II.

Pembelajaran tindakan siklus II diberikan agar dapat menentukan langkah-langkah untuk menyelesaikan soal-soal penjumlahan pecahan biasa berpenyebut tidak sama yang salah satu pembilangnya 1 dengan menggunakan gambar luas daerah yang diarsir. Pembelajaran tindakan siklus II dilaksanakan dalam satu kali pertemuan dengan alokasi waktu $2 \times 30$ menit. Indikator pembelajaran adalah siswa mampu melakukan pembelajaran, pengurangan, perkalian, dan pembagian pecahan, menentukan langkahlangkah untuk menyelesaikan soal-soal penjumlahan biasa berpenyebut tidak sama dan salasatu penyebutnya merupakan penyebut yang 
lain serta salah satu pembilangnya 1 serta menentukan langkah-langkah untuk menyelesaikan soal-soal penjumlahan pecahan biasa berpenyebut tidak sama dan penyebutnya bukan kelipatan salah satunya.

Dalam rencana pembelajaran selain indikator pembelajaran juga memuat materi pembelajaran, materi prasyarat, alat dan sumber serta kegiatan pembelajaran. Seperti pada tindakan siklus I, dalam pelaksanaan tindakan siklus II pengamat melakukan pengamatan sesuai lembar pengamatan yang disiapkan peneliti. Peneliti juga menyiapkan LKS, soal tes, dan kertas karton yabng terdiri dari dua warna yaitu hitam dan putih. Adapun rencana pelaksanaan pengajaran tindakan siklus II dapat dilihat pada lampiran 7 .

\section{b. Pelaksanaan Siklus II}

Pembelajaran tindakan siklus II dilaksanakan pada hari Senin tanggal 24 Mei 2016 mulai pukul 09.40-11.00 WITA. Pembelajaran pada tindakan II berlangsung selama 70 menit atau 2 jam pelajaran. Peneliti tetap sebagai guru seperti halnya dalam tindakan siklus I. Pembelajaran diawali dengan mengucapkan salam dan menyampaikan materi yang akan dipelajari yaitu operasi penjumlahan pecahan dengan menggunakan luas daerah bagian sebagai media pembelajaran. Setelah itu peneliti menyampaikan indikator yang akan dicapai.

Sebelum kegiatan inti dalam pembelajaran, peneliti memulai dengan kegiatan awal yaitu memotivasi siswa dengan menunjukkan beberapa pecahan yang berbedabeda dalam bentuk luasan daerah kemudian siswa diberi pertanyaan bagaimana menjumlahkan pecahan tersebut (pecahan biasa berpenyebut tidak sama) secara tepat dan seorang siswa diminta untuk menjawabnya. Untuk melacak pemahaman siswa, peneliti juga meminta siswa menentukan KPK dua bilangan dan pecahan senilai.

\section{c. Analisis dan Refleksi siklus II}

Pembelajaran tindakan siklus II difokuskan pada penjumlahan pecahan biasa dengan menggunakan luasan daerah yang diarsir. Pembelajaran pada tindakan siklus II ini juga menerapkan belajar klasikal dan untuk memperoleh data tentang pelaksanaan tindakan siklus II dilakukan pengamatan, wawancara, tes, dan catatan lapangan. Selama pelaksanan tindakan dianalisis dan didiskusikan dengan pengamat diperoleh hal-hal sebagai berikut

1. Penyajian pada tahap presentasi untuk meragakan langkah-langkah menyelesaikan soal untuk penjumlahan pecahan biasa dengan menggunakan gambar luas daerah berlangsung sesuai rencana.

2. Siswa merasa senang mengerjakan soal penjumlahan pecahan dengan alat peraga berupa karton berbentuk persegi panjng, segitiga dan lingkaran yang disediakan

3. Siswa tidak mengalami kesulitan membagi bagian yang sama besar setelah diberi bimbingan seperlunyaoleh peneliti. Akhirnya siswa dapat mengerjakan sendiri

4. Siswa dapat menentukan langkah-langkah menyelesaikan soal untuk memperoleh hasil penjumlahan pecahan dengan menggunakan gambar luas daerah

5. Hasil tes tindakan siklus II menunjukan kemajuan, semua subyek penelitian memperoleh skor sesuai dengan yang diharapkan.

Berdasarkan hasil analisis dan refleksi dan mengacu pada kriteria sukses yang ditetapkan maka pembelajaran telah selesai. Dimana siswa telah memiliki pemahaman tentang penjumlahan pecahan dengan nilai ratarata 7,5. Hasil tes dapat dilihat pada lampiran 17.

\section{PEMBAHASAN}

1. Temuan Penelitian Tindakan siklus 1

Beberapa temuan yang diperoleh pada pelaksanaan tindakan I adalah sebagai berikut

a. Siswa merasa senang belajar dengan menggunakan gambar luas daerah. Hal ini ditunjukkan dengan sikap aktif dan antusias waktu mereka bekerja menyelesaikan soal penjumlahan pecahan

b. Penggunaan gambar luas daerah membantu siswa dapat menentukan langkah-langkah untuk menyelesaikan soal penjumlahan pecahan yang berpenyebut sama

c. Siswa senang menggunaan alat peraga dalam mengikuti pembelajaran. Mereka kelihatan seperti bermain namun tetap serius mengerjakan tugas

d. Berdasarkan hasil tes awal dan hasil wawancara dengan subyek penelitian siswa dapat memahami materi dengan baik.

e. Siswa terlibat aktif dalam tugas kelompok. Mereka bekerja sama dalam kelompok dan memberi kepercayaan kepada teman dalam 
menyelesaikan tugas tanpa memandang perbedaan kemampuan.

f. Siswa dalam menyelesaikan dalam menyelesaikan soal penjumlahan pecahan memberi pendapat dan ide serta memperhatikan pendapat yang disampaikan teman kelompok.

g. Siswa yang mengalami kesulitan menyelesaikan tugas bertanya kepada teman dalam kelompok terlebih dahulu sebelum bertanya kepada guru.

h. Kegiatan belajar dalam kelompok membutuhkan waktu yang lebih lama dari yang direncanakan. Alokasi waktu dalam kegiatan belajar kelompok 30 menit tetapi pada pelaksanaannya membutuhkan waktu 40 menit.

\section{Temuan Penelitian Tindakan Siklus II}

Beberapa temuan yang diperoleh pada pelaksanaan siklus II sama dengan temuan tindakan I yaitu

a. Siswa merasa senang belajar dengan menggunakan gambar luas daerah. Hal ini ditunjukkan dengan sikap aktif dan antusias waktu mereka bekerja menyelesaikan soal penjumlahan pecahan

b. Penggunaan gambar luas daerah membantu siswa dapat menentukan langkah-langkah untuk menyelesaikan soal penjumlahan pecahan yang berpenyebut sama

c. Siswa senang menggunaan alat peraga dalam mengikuti pembelajaran. Mereka kelihatan seperti bermain namun tetap serius mengerjakan tugas

d. Berdasarkan hasil tes awal dan hasil wawancara dengan subyek penelitian siswa dapat memahami materi dengan baik.

e. Siswa terlibat aktif dalam tugas kelompok. Mereka bekerja sama dalam kelompok dan memberi kepercayaan kepada teman dalam menyelesaikan tugas tanpa memandang perbedaan kemampuan.

f. Siswa dalam menyelesaikan dalam menyelesaiakn soal penjumlahan pecahan memberi pendapat dan ide serta memperhatikan pendapat yang disampaikan teman kelompok.

g. Siswa yang mengalami kesulitan menyelesaikan tugas bertanya kepada teman dalam kelompok terlebih dahulu sebelum bertanya kepada guru.

h. Kegiatan belajar dalam kelompok membutuhkan waktu yang lebih cepat dari yang direncanakan. Alokasi waktu dalam kegiatan belajar kelompok 30 menit tetapi pada pelaksanaannya membutuhkan waktu 25 menit.

\section{Pembahasan}

Hasil penelitian terhadap aktifitas dan hasil belajar dengan menggunakan gambar luas daerah, melalui tiga tahapan yaitu, konsep pacahan, pecahan senilai, dan penjumlahan pecahan. Pada siklus pertama tindakan siklus I dan tindakan siklus II mengalami peningkatan yang signifikan.

Hasil tindakan siklus I pertama belum mencapai hasil yang diharapkan karena sebagian subyek belum memahami pecahan, yang terdiri dari menentukan KPK, pecahan senilai, dan penjumlahan pecahan. pada tahap pertama menggunakan gambar luas daerah dalam penjumlahan pecahan siswa belum dapat menentukan lambang bilangan pecahan daerah yang diarsir, Namun siswa aktif dalam pembelajaran dan menyadari pentingnya memahami operasi penjumlahan pecahan. Hal ini terbukti bahwa siswa sudah memahami penjumlahan pecahan yang luas, akan menghasilkan pengetahuan yang berarti dalam kehidupan sehari-hari.

Siswa juga sudah memilih topik yang menarik sesuai kenyataan yang ia alami dalam kehidupannya, hal ini menunjukan bahwa siswa yang telah memahami konsep penjumlahan pecahan merupakan syarat pembelajaran yang baik, artinya penilaian dapat memacu semangat untuk mengembangkan pembelajaran khususnya dalam penjumlahan pecahan.

Keberhasilan tindakan siklus II mencapai kualifikasi yang sangat baik karena pada kegiatan yang terakhir dalam penjumlahan pecahan siswa mampu menjumlahkan pecahan dengan menggunakan gambar luas daerah arsiran. Hal ini menunjukan bahwa siswa telah memahami makna model dan luas daerah arsiran pada pecahan, sejalan dengan penjelasan dan prediksi (Herawati,1994: 94) bahwa dalam pembelajaran matematika utamanya pada jenjang sekolah dasar sangat diperlukan suatu teknik yang tepat agar konsep matematika yang diajarkan dapat dipahami dengan baik oleh siswa. Salasatu teknik yang digunakan adalah penggunaan gambar luas daerah sebagai media pembelajaran untuk menjelaskan suatu konsep khususnya penjumlahan bilangan pecahan, serta bertujuan untuk mengurangi tingkat abstraksi siswa Soejadi (Herawati,1994:15) 
Keberhasilan siklus dari tindakantindakan karena siswa telah memahami konsep penjumlahan pecahan, yaitu menentukan lambang bilangan pecahan, kelipatan persekutuan terkecil (KPK) dan pecahan senilai. Langkah-langkah mempergunakan konsep pecahan meningkatkan pemahaman siswa terhadap operasi penjumlahan bilangan pecahan.

Keberhasilan PTK dari tindakan ketindakan karena siswa telah memahami tahaptahap operasi penjumlahan bilangan pecahan yaitu pengembangan seluruh pada tahap penanaman konsep. Pada tahap ini siswa memahami nilai pecahan yang dijumlahkan, mengapa hasilnya begini atau begitu, apa manfaat dan tujuan penjumlahan dan bagaimana aplikasinya dalam kehidupan sehari-hari. Kemampuan siswa pada penjumlahan pecahan dengan menggunakam gambar luas daerah. Nampak bahwa pembelajaran belajar dengan menggunakan alat peraga luas daerah bangun persegi dapat meningktkan pemahaman siswa penjumlahan pecahan.

\section{SIMPULAN DAN SARAN}

Penggunaan gambar luas daerah dalam pembelajaran penjumlahan pecahan dapat meningkatkan pemahaman siswa kelas VI SD Negeri 9 Ta' . Hal ini dapat dilihat pada perkembangan setiap siklus. Pada siklus I belum menunjukkan hasil yang memuaskan setelah siklus II siswa telah memperoleh pemahaman tentang penjumlahan pecahan.

Proses pembelajaran dengan menggunakan gambar luas daerah dari aspek guru dan siswa dapat dicapai karena dari tindakan ketindakan refleksi dan perbaikan dengan melalui kolaborasi yang baik dengan pihak terkait dalam penelitian. Hasil belajar dengan menggunakan gambar luas daerah siswa kelas VI SD Negeri 9 Ta' telah mengalami peningkatan khususnya pada pembelajaran penjumlahan pecahan.

1. Kepada guru SD agar menggunakan gambar luas daerah sebagai salasatu alternatif meningkatkan pemahman dan hasil belajar siswa dalam pembelajaran operasi penjumlahan bilangan pecahan

2. Kepada mahasiswa yang akan melaksanakan PPL diharapkan dapat menerapkan penggunaan gambar luas daerah dalam pembelajaran penjumlahan pecahan juga kelak nanti menjadi guru

\section{DAFTAR PUSTAKA}

Arsyad Azhar, 2004. Media Pembelajaran. Jakarta: PT Raja Grafindo Persada.

Hartono P. 2003. Tahap-Tahap Perkembangan Kognitif Siswa: Depdiknas Jakarta

Herawati Susi.1994. Memantapkan Penggunaan Model Bagian Suatu Daerah Untuk Mengajarkan Penjumlahan Pecahan: IKIP SURABAYA

Hudoyo, Herman. 1990. Mengajar Beajar Matematika Usaha Nasional : Surabaya

$\begin{array}{ccc}\text { Kurikulum } & 1996 . \quad \text { Pengembangan } \\ \text { Matematika dan }\end{array}$

Pelaksanaannya di Depan Kelas. Usaha Nasional: Suarabaya

Inganah S. 2003. Model Pembelajaran Segi Empat Dengan Pendekatan Realistik Pada Siswa Kelas II SLTP Negeri III Batu. Tesis Tidak Diterbitkan

Latri. 2003. Pembelajaran Volume Kubus dan Balok Secara Kontribusi Dengan Menggunakan Alat Peraga di Kelas VI SDN 10 Watampone. Proposal Tesis Tidak Diterbitkan

Miles, M.B dan Huberman. Analisis Data Kualitatif. Terjemahan oleh Tjeptjep Rohidi 1992 Jakarta UI Press

Moleong, L.J 1994 Metodologi Penelitian Kualitatif. Remajarosdakarya. Bandung

Muhsetio G. 2005. Pembelajaran Matematika di $S D$ : Universitas Terbuka

Ramadhoni,R. 1996. Anlisis Kemampuan Menyelesaikan Kemampuan Operasi Pecahan dalam Soal Cerita Matematika. Skripsi. FPMIPA IKIP Ujung Pandang.

Roi Jokers. 1991. Mengajar dengan Sukses : Gresindo Jakarta

Rusiyan, Tabrani. 1989. Pendekatan Dalam Proses Belajar Mengajar : Remaja Karya Bandung

Susanto, 2007. Pengembangan KTSP Dengan Manajemen Visi. Jakarta

Soenarto Sunaryo. 2002. Interaksi Pembelajaran dan Pengelolaan Kelas. Depdiknas: Jakarta

Sukarman, Herry. 2002. Pengelolaan Proses Belajar Mengajar. Depdiknas.

Tiro, M Arif 1994. Cara Mengajar Konsep Pecahan di Sekolah Dasar "Transfprmasi" Vol. 1 1994. Ujung pandang. 
JIKAP PGSD: Jurnal Ilmiah Ilmu Kependidikan

Winkel, W.S. 1991. Psikologi Pengajaran. Remaja Karya: Bandung

Wiriaatmadja R, 2005. Metode Penelitian Tindakan Kelas. Remaja Rosda Karya: Bandung 